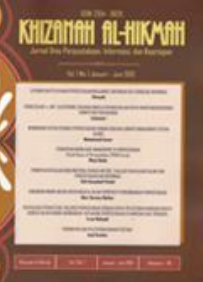

\title{
BIBLIOMETRIC ANALYSIS ON RESEARCH STUDY OF POMEGRANATE: a review towards new findings
}

\author{
Khadher Ahmad, Mohd Yakub @ Zulkifli Mohd Yussuf, Nurulwahidah Fauzi, \\ Monika @ Munirah Abd Razak, Mohd Asmadi Yakob, Khalijah Awang, Rozana \\ Othman, and Mohd Farhan Md Ariffin*
}

Pengutipan: Ahmad, K. et al. (2015). Bibliometric analysis on research study of pomegranate: a review toward new findings. Jurnal Ilmu Perpustakaan, Informasi, dan Kearsipan Khizanah AlHikmah, 3(1), 21-39. Diambil dari http://http://journal.uin-alauddin.ac.id/index.php/khizanah-alhikmah/article/view/586

*Informasi mengenai para penulis dapat dilihat di halaman terakhir artikel ini

\begin{abstract}
ABSTRAK
Delima merupakan buah yang mengandung banyak kekayaan anti oksidan dan juga dapat digunakan sebagai alternatif dan bahan obat-obatan alami. Dari sudut pandang ilmu kesehatan pada masa lalu, delima termasuk dalam buah-buahan yang baik untuk kesehatan karena manfaatnya yang dapat mengobati beberapa jenis penyakit. Penelitian ini membahas tentang tren pada publikasi-publikasi mengenai delima. Penelitian ini difokuskan pada analisis konten, khususnya pada publikasi-publikasi penting tentang delima. Penelitian ini menunjukkan bahwa 85,5 persen penelitian-penelitian yang membahas tentang delima banyak terbit dalam bentuk jurnal artikel. Metode penelitan yang banyak digunakan pada penelitian-penelitian tersebut ialah analisis ilmiah (penelitian laboratori). Kajian mengenai aspek keilmuan dibagi menjadi tujuh bagian di antaranya diskusi ilmiah tentang delima yaitu farmasi, ilmu makanan, botani, biomedis, biokimia dan mikrobiologi. Hanya satu kajian yang fokus pada analisis keislaman yaitu pada sektor Pendidikan Islam. Bidang lainnya mengenai Lingkungan Pendidikan (Tumbuh-tumbuhan) juga terdapat pada penelitian ini yaitu dimaksudkan untuk mengumpulkan data dan menemukan hasil tentang tumbuh-tumbahan delima.
\end{abstract}

Kata Kunci: bibliometrik, tren penelitian, delima, produk Malaysia

\section{ABSTRACT}

Pomegranates are an antioxidant-rich superfood with alternative and natural medicine resources for the natural health community. From the perspective of ancient medical practice, pomegranate is in a highest ranking of healthy fruits because of its diverse beneficial in curing diseases. Trend research publications pomegranates were studied. The study focused on content analysis, especially in the field of primary research on pomegranate. Referring to the results of 'literature review' on pomegranate, researchers found that the majority of previous research on pomegranate dominated by journal articles by 85.5 percent. Research on the method of analysis conducted in the previous studies found that most studies on pomegranate done on a scientific analysis (laboratory studies). Studies on aspects of science has been divided into seven areas. Focus areas include scientific discussion of pomegranate is pharmaceutical, Food Science, Botany, Bio-Medical, Bio-Chemistry and Microbiology. Only one field of study that focuses on the analysis of Islamic view focusing on Islamic Education. Additional fields of Environmental Education (Flora) are also included by researchers to collect data and find a results on plants that contain pomegranate. Comparative evaluation of research found that a total of $188 \mathrm{kinds}$ of studies involves the study of the scientific aspects compared to only 11 studies based on Islam (Islamic Education) and 10 studies based on environmental education. Thus, the efforts of researchers from Universiti Malaya through grants TRGS (TR001A2014) entitled 'Safe and Health Uses of Fruits and Herbs Mentioned in Al-Quran and Ahadith: An Analysis of ethnomedicinal Importance in Islamic Products in Malaysia' are very significant in the development of science. Advanced new study of henna is expected to produce benefits to Malaysia as a whole.

Key Words: bibliometrics, research trend, pomegranates, Malaysian product 


\section{INTRODUCTION}

Study design can be used as an indicator of research productivity and trends of research in various disciplines. This study could also determine research priorities in matters related to publishing. The aim of this study is to analyze the writing of articles by field or specific research discipline. Articles published in any discourse is usually a result of recent research that can be developed, shared and distributed to serve as a reliable scientific references. This is due to the process of publishing scientific materials that have to go through a screening process and a review by experts in the field to ensure that the published material, not only to comply with the characteristics for publication in scientific journals or materials, but also to ensure that research conducted in accordance with proper procedures.

\section{POMEGRANATE: DEFINITION AND DESCRIPTION}

The pomegranate, botanical name 'Punica Granatum', is a fruit bearing deciduous shrub that contain thousands of health benefits. This fruit is called three times in the Holy Quran, thus showing it advantages and privileges as fruits that are beneficial to human being. In English terms, the pomegranate is known as the 'pomegranate' and 'al-Rumman' or 'alRummanah' in Arab.

\section{Oxford English Dictionary defines} Pomegranate as a word derives from medievel Latin pōmum (apple) and granatum (seeded). According to ancient French language, pomegranate are called pomme granatum which means apple (pomme) and granatum that refers to the seedless fruits that originated from Granada. In fact, the Encyclopedia Britannica states that the city of Granada in southern Spain got its name from the pomegranate as a local fruit's in there.

Pomegranate or Punica granatum, is a fruit-bearing deciduous shrub or small tree growing between 5 and $8 \mathrm{~m}(16-26 \mathrm{ft})$ tall. The pomegranate is considered to have originated from the area of Southwest Asia and has grown naturally in the entire Mediterranean region and the Caucasus since ancient times. It is widely cultivated throughout Afghanistan, Algeria, Armenia, Azerbaijan, Iran, Iraq, India, Pakistan, Syria, Turkey, Peninsular Malaysia, Eastern India and tropical regions of Africa. Pomegranate brought into Latin America and California by Spanish settlers in 1769 and grown in California and Arizona for some juice production.

Pomegranates are an antioxidant-rich superfoods as having four parts that can be exploited by human. It consists of fruit, bark, roots and juice (water landing). In the food industry, pomegranate fruit species categorized as exotic and nutririous food supply. Types of pomegranate are different shapes, colors, grains and different levels of sweetness and acidity. Type the best pomegranate pomegranate color is the brightest, thin-skinned and many water content.
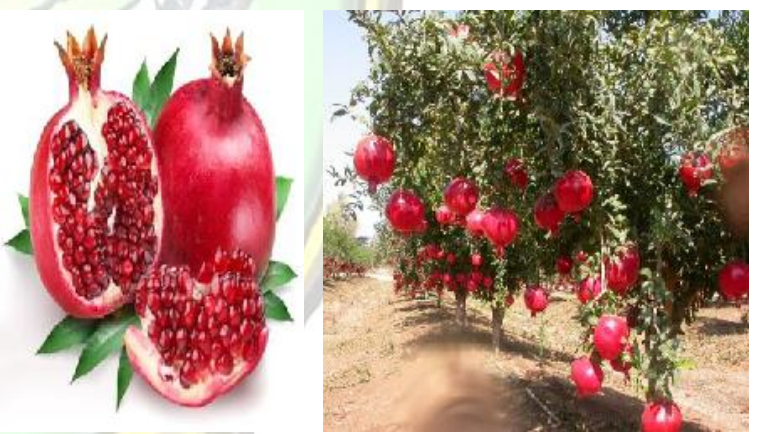

\section{SCOPE AND METHODOLOGY}

This study applied the bibliometric analysis to study the results of previous research related with pomegranate. Bibliometric analysis is a method for assessing and measuring the information in the text and publications. It is not only frequently used in the field of library of information science but 
also widely used in other areas in the form of citation analysis (citation) and content analysis.

Search method is important to ensure that any data on research areas can be found effectively. Through the following search keywords, researchers are able to found the articles, books, magazines and pomegranate completely. Search keywords are as follows

\section{Keyword Search}

1. Delima

(Malay + PDF words)

2. Punica Granatum

3. Pomegranate

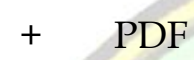

4. الرمَّمان

5.

Figure 1. the technique to obtain data

After all the data is collected, it will be scanned manually and classified using Microsoft Office Excel. Data that has been listed then be analyzed using statistical program SPSS (Statistical Package for the Social Sciences).

4. LITERATURE POMEGRANATE

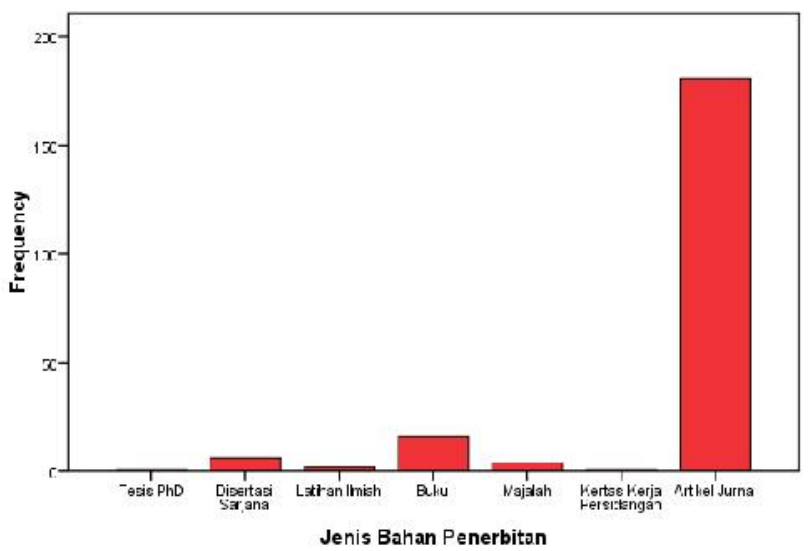

Figure 2. Publications types
Referring to the diagram above, the results of previous research on pomegranate found that majority of study are dominated by journal articles by $85.8 \%$. Books were in the second highest percentage of $7.6 \%$. This was followed by a master dissertation with the percentage of $2.8 \%$, and project paper by $0.9 \%$. The lowest percentage recorded $\mathrm{PhD}$ thesis and conference papers by the same percentage by $0.5 \%$. List of materials related publications pomegranate can be examined through the following table.

\section{LIST OF PUBLICATIONS ON POMEGRANATE}

\section{PhD Thesis}

1. Nauli, Rizki Rahma. 2010. Pengaruh Pemberian Ekstrak Kulit Buah Delima Putih (Punica Granatum Linn) Dan Ketokonazol 2\% Terhadap Pertumbuhan Candida Albicanssecara In Vitro Pada Kandidiasis Vulvovaginalis. Skripsi. Program Pendidikan Sarjana Kedokteran, Fakultas Kedokteran. Semarang: Universitas Diponegoro Master Dissertation

1. Sugianto, Nanik Lidyawati. 2011. Pemberian Jus Delima Merah (Punica Granatum) Dapat Meningkatkan Kadar Glutation Peroksidase Darah Pada Mencit (Mus Musculus) Dengan Aktivitas Fisik Maksimal. Tesis: Program Magister, Program Studi Ilmu Biomedik, Program Pascasarjana. Denpasar: Universitas Udayana

2. Wirawan, Hans Ceisar. 2008. Pengaruh ekstrak delima putih (punica granatum, l) terhadap proliferasi alur sel leukimia (thp-1) secara in Vitro. Skripsi. Fakultas Teknologi Pertanian. Bogor. Institut Pertanian Bogor

3. Ade Indah Pratiwi, 2014. Manfaat Berkumur Sari Buah Delima Merah (Punica Granatum) Terhadap Penurunan akumulasi Plak Gigi, Skripsi Sarjana Kedokteran Gigi. Fakultas Kedokteran Gigi Universitas Mahasaraswati Denpasar

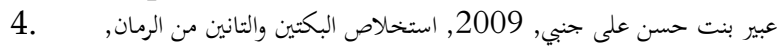

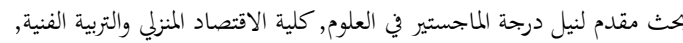

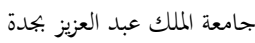

5. Nor Azma Hannah Mazlan, 2004. Cytoprotection effects by honey alone or in combination with methanol extract of punica granatum L. and ethanol extract of nigella sativa L. on ethanol-induced gastric damage in rats. 
Disertasi Sarjana. Jabatan Perubatan Molekul, Fakulti Perubatan, Kuala Lumpur: Universiti Malaya

6. 6 6زت فارس, الرمان: غداء ودواء, ماجستير تغذية الإنسان, قسم التغذية, كلية الصيدلة والعلوم الطبية, جامعة البترا الأردنية

\section{Project Paper}

1. Nooradilah Binti Ab.Kadir, Makanan Berkhasiat Menurut Perspektif Al-Quran, Latihan Ilmiah bagi memenuhi keperluan ijazah Sarjana Muda, Jabatan Al-Quran dan Al-Hadith Akademi Pengajian Islam Universiti Malaya sesi 2010/2011

2. Siti Rudainah Bt Saleh, Pemakanan di dalam Al-Quran dan Al-Hadith. Latihan Ilmiah bagi memenuhi keperluan ijazah Sarjana Muda Usuluddin, Akademi Pengajian Islam Universiti Malaya sesi 1997/1998

\section{Conference Papers}

1. Arshi Malik, Farrukh Afaq, Sami Sarfaraz, Vaqar M. Adhami, Deeba N. Syed, and Hasan Mukhtar, Pomegranate fruit juice for chemoprevention and chemotherapy of prostate cancer, Proceedings of the National Academy of Sciences of the United States of America, October 11, 2005, vol. 102, no. 41

\section{Books}

1. Fairuzah Tsabit, 2013, Makanan Sehat Dalam Al-Quran, Yogyakarta: Pustaka Ilmu

2. Ibn Qayyim al-Jawziyyah, Perubatan Rasullullah, (terj.) Nabilah Abd. Jalil, 2013, Selangor: Al-Hidayah House of Publishers Sdn. Bhd

3. Jamaluddin Mahran, 'Abd al-'Azim Hafna Mubashir, al-Ghadza' wa al-Dawa' fi alQur'an al-Karim, (terj.) Al-Qur'an Bertutur Tentang Makanan \& Obat-Obatan, Yogyakarta: Mitra Pustaka

4. Rukayah Aman, 1999. Buah-Buahan Malaysia, Kuala Lumpur: Dewan Bahasa dan Pustaka

5. Rukayah Aman, 2001. Buah-buahan Nadir Semenanjung Malaysia. Kuala Lumpur: Dewan Bahasa dan Pustaka

6. Ismail Saidin, 2013, Dusun Melayu, Kuala Lumpur: Dewan Bahasa dan Pustaka

7. Mohamed Roselan Ab Malek, 2010, Tumbuhan Berbuah, Petaling Jaya: Nikaz Publications

8. Dr. Zaid bin Muhammad al-Rummani, 2009, Penawar Dalam Buah Delima, Makanan Syurga dan Ubat, (terj.) Faisal Saleh, Kuala Lumpur: al-Hidayah

9. Eric M.Oey, 1996, Tropical Fruits of Malaysia $\mathcal{E}$ Singapore, Hong Kong: Periplus Editions (HK) Ltd
10. Chin Hoong Fong, Yong Hoi-Sen, 2000, Malaysian Fruits in Colour, Bangsar: Tropical Press Sdn Bhd

11. Desmond Tate, 1999, Tropical Fruit, New York: Archipelago Press

12. Abu 'Ali al-Husayn bin 'Abd Allah Ibn Sina, 1998, Al-Qanun fi al-Tibb, Beirut: Muassasah al-Ma'arif

13. Abu 'Abd Allah Muhammad bin Ahmad alDhahabi, 1990, Al-Tibb al-Nabawi, Beirut: Dar Ihya' al-`Ulum

14. Muhammad al-Sayyid Arna'ut, 1998, AlA'shab wa al-Nabatat Ghiza' wa Dawa', Kaherah: al-Dar al-Misriyyah alLubnaniyyah

15. Shams al-Din Muhammad bin Abu Bakr Ibn Qayyim al-Jawziyyah, 1990, Al-Tibb alNabawi, Beirut: Dar al-Fikr

16. فراس ارشيد, 2012, البرنامج المتكامل لخدمة اشجار الرمان, السلطة الوطنية الفلسطينية وزارة الزراعة, نشرة رقم: 35

\section{Magazines}

1. Zuarida Mohyin, Buah Delima Kurangkan Risiko Sakit Jantung, majalah Al-Islam, Februari 2001

2. Purwantini, Indah dan Subagus Wahyuono. Isolation and identification of antifungal (candida albicans) compound from the hull of delima fruits (punica granatum). Majalah Farmasi Indonesia. UGM Yokyakarta

3. Dr. Ong Hean Choi, Delima, Dewan Kosmik, Ogos 2003

4. Suzanne Jorgensen, Charlotte Brennard, Pomegranates, Preserve the Harvest, bilangan 7, Jun 2005

\section{RESULTS}

Based on previous studies, research on pomegranate are divided and alnalyzed according to eight key areah. Discussion of the findings are as follows;

\section{ENVIRONMENTAL EDUCATION (FLORA)}

1. Suzanne Jorgensen, Charlotte Brennard, Pomegranates, Preserve the Harvest, bil. 7, Jun 2005

2. Dr. Ong Hean Choi, Delima, Dewan Kosmik, Ogos 2003

3. , 2012, ارشيد,

35 :

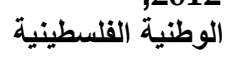

4. Desmond Tate, 1999, Tropical Fruit, New York: Archipelago Press

5. Chin Hoong Fong, Yong Hoi-Sen, 2000, 
Malaysian Fruits in Colour, Bangsar: Tropical Press Sdn Bhd

6. Eric M.Oey, 1996, Tropical Fruits of Malaysia \& Singapore, Hong Kong: Periplus Editions (HK) Ltd

7. Mohamed Roselan Ab Malek, 2010, Tumbuhan Berbuah, Petaling Jaya: Nikaz Publications

8. Ismail Saidin, 2013, Dusun Melayu, Kuala Lumpur: Dewan Bahasa dan Pustaka

9. Rukayah Aman, 2001. Buah-buahan Nadir Semenanjung Malaysia. Kuala Lumpur: Dewan Bahasa dan Pustaka

10. Rukayah Aman, 1999. Buah-Buahan Malaysia, Kuala Lumpur: Dewan Bahasa dan Pustaka

\section{ISLAMIC EDUCATION}

1. Munirah Abd Razzak, 2011, Punica Granatum Bicara Al-Quran Al-Hadith Dan Sains Perubatan Moden, Jurnal Al-Bayan, bil. 9(1), Universiti Malaya: Jabatan AlQur'an dan Al-Hadith, Akademi Pengajian Islam

2. Shams al-Din Muhammad bin Abu Bakr Ibn Qayyim al-Jawziyyah, 1990, Al-Tibb alNabawi, Beirut: Dar al-Fikr

3. Muhammad al-Sayyid Arna'ut, 1998, AlA'shab wa al-Nabatat Ghiza' wa Dawa', Kaherah: al-Dar al-Misriyyah alLubnaniyyah

4. Abu 'Ali al-Husayn bin 'Abd Allah Ibn Sina, 1998, Al-Qanun fi al-Tibb, Beirut: Muassasah al-Ma'arif

5. Abu 'Abd Allah Muhammad bin Ahmad al-Dhahabi, 1990, Al-Tibb al-Nabawi, Beirut: Dar Ihya' al-'Ulum

6. Dr. Zaid bin Muhammad al-Rummani, 2009, Penawar Dalam Buah Delima, Makanan Syurga dan Ubat, (terj.) Faisal Saleh, Kuala Lumpur: al-Hidayah

7. Jamaluddin Mahran, 'Abd al-'Azim Hafna Mubashir, al-Ghadza' wa al-Dawa' fi alQur'an al-Karim, (terj.) Al-Qur'an Bertutur Tentang Makanan $\mathcal{E}$ Obat-Obatan, Yogyakarta: Mitra Pustaka

8. Ibn Qayyim al-Jawziyyah, Perubatan Rasullullah, (terj.) Nabilah Abd. Jalil, 2013, Selangor: Al-Hidayah House of Publishers Sdn. Bhd

9. Fairuzah Tsabit, 2013, Makanan Sehat Dalam Al-Quran, Yogyakarta: Pustaka Ilmu

10. Siti Rudainah Bt Saleh, Pemakanan di dalam Al-Quran dan Al-Hadith. Latihan Ilmiah bagi memenuhi keperluan ijazah Sarjana Muda Usuluddin, Akademi Pengajian
Islam Universiti Malaya sesi 1997/1998

11. Nooradilah Binti Ab.Kadir, Makanan Berkhasiat Menurut Perspektif Al-Quran, Latihan Ilmiah bagi memenuhi keperluan ijazah Sarjana Muda, Jabatan Al-Quran dan Al-Hadith Akademi Pengajian Islam Universiti Malaya sesi 2010/2011

1. Pharkphoom

Panichayupakaranant, Atcharaporn Itsuriya and Anusak Sirikatitham, 2010, Preparation method and stability of ellagic acid-rich pomegranate fruit peel extract, Pharmaceutical Biology, 48(2) , pp. 201-205

2. Tom Hsun-Wei Huang, 2005, Pomegranate Flower Improves Cardiac Lipid Metabolism In A Diabetic Rat Model: Role Of Lowering Circulating Lipids, British Journal of Pharmacology, 145(6), pp. 767-774

3. E.Y. Qnais, A.S. Elokda, Y.Y. Abu Ghalyun, and F.A. Abdulla, 2007, Antidiarrheal Activity of the Aqueous Extract of Punica granatum. (Pomegranate) Peels, Pharmaceutical Biology, 45(9), pp. 715-720

4. Ahmed R, Ifzal SM, Saifuddin A, Nazeer M. 1995, Short communication: studies on punica granatum-I isolation and identification of some constituents from the seeds of punica granatum. Pakistan Journal of Pharmaceutical Sciences, 8(1), pp. 69-71

5. L.C. Bragaa, et.al. 2005, Pomegranate extract inhibits Staphylococcus aureus growth and subsequent enterotoxin production, Journal of Ethnopharmacology, 96(1-2), pp. 335-339

6. Tom H.W. Huang, et.al. 2005, Anti-diabetic action of Punica granatum flower extract: Activation of PPAR- $\gamma$ and identification of an active component, Toxicology and Applied Pharmacology, 207(2), pp. 160-169

7. Dora Farkas, et.al. 2007. Pomegranate Juice Does Not Impair Clearance of Oral or Intravenous Midazolam, a Probe for Cytochrome P450-3A Activity: Comparison With Grapefruit Juice, The Journal of Clinical Pharmacology, 473, pp. 286294

8. Hamid Reza Rahimi, Mohammad Arastoo and Seyed Nasser Ostad, A Comprehensive Review of Punica granatum (Pomegranate) Properties in Toxicological, Pharmacological, Cellular and Molecular Biology Researches, Iran J. Pharm. Res. 2012 Spring, 11(2), pp. 385-400.

9. K.B. Ajaikumar, M. Asheef, B.H. Babu, J. 
Padikkala, 2005, The inhibition of gastric mucosal injury by Punica granatum L. (pomegranate) methanolic extract, Journal of Ethnopharmacology, 96(1-2), pp. 171-176

10. Alexis Vidala, et.al. 2003, Studies on the toxicity of Punica granatum L.(Punicaceae) whole fruit extracts, Journal of Ethnopharmacology, 89(23), pp. 295-300

11. M.A Jafria, M Aslama, Kalim Javeda, Surender Singh, 2000. Effect of Punica granatum Linn. (flowers) on blood glucose level in normal and alloxan-induced diabetic rats, Journal of Ethnopharmacology, 70(3), pp. 309-314

12. Yuhao Lia, et.al. 2005. Punica granatum flower extract, a potent a-glucosidase inhibitor, improves postprandial hyperglycemia in Zucker diabetic fatty rats, Journal of Ethnopharmacology, 99(2), pp. 239-244

13. Mario Dell'Aglia, et.al. 2009, Antiplasmodial activity of Punica granatum L. fruit rind, Journal of Ethnopharmacology, 125(2), pp. 279-285

14. Asish K Dasa, et.al. 1999. Studies on antidiarrhoeal activity of Punica granatum seed extract in rats, Journal of Ethnopharmacology, 68(1-3), pp. 205-208

15. Shay Yehoshua Schubert, et.al. 1999. Antioxidant and eicosanoid enzyme inhibition properties of pomegranate seed oil and fermented juice flavonoids, Journal of Ethnopharmacology, 66(1), pp. 11-17

16. Angel Sánchez-Lamara, et.al. 2008, Assessment of the genotoxic risk of Punica granatum $L$. (Punicaceae) whole fruit extracts, Journal of Ethnopharmacology, 115(3), pp. 416-422

17. Ephraim P. Lansky, Robert A. Newman, 2007. Punica granatum (pomegranate) and its potential for prevention and treatment of inflammation and cancer, Journal of Ethnopharmacology, 109(2), pp. 177-206

18. R. Gracious Ross, S. Selvasubramanian, S. Jayasundar, 2001, Immunomodulatory activity of Punica granatum in rabbits-a preliminary study, Journal of Ethnopharmacology, 78(1), pp. 85-87

19. Swathi Voruganti, et.al. 2012, Effect of Pomegranate Juice on Intestinal Transport and Pharmacokinetics of Nitrendipine in Rats, Phytotherapy Research, 26(8), pp. 1240-1245

\section{NUTRITIONAL SCIENCE}

1. Antonio González-Sarrías, 2010, Occurrence of urolithins, gut microbiota ellagic acid metabolites and proliferation markers expression response in the human prostate gland upon consumption of walnuts and pomegranate juice, Molecular Nutrition \& Food Research, 54(3), pp. 311-322
2. Mohamed Neifar, et.al. 2011, Effective Clarification Of Pomegranate Juice Using Laccase Treatment Optimized By Response Surface Methodology Followed By Ultrafiltration, Journal of Food Process Engineering, 34(4), pp. 1199-1219

3. Manoj Mundada, Bahadur Singh Hathan and Swati Maske, 2011. Mass Transfer Kinetics during Osmotic Dehydration of Pomegranate Arils, Journal of Food Science, 76(1), pp. 31-39

4. Mustafa Ozgen, Coşkun Durgaç, Sedat Serçe, Cemal Kaya, 2008, Chemical and antioxidant properties of pomegranate cultivars grown in the Mediterranean region of Turkey, Food Chemistry, 111(3), pp. 703706

5. Hossein Mirsaeedghazi, et.al. 2010. Effect of membrane clarification on the physicochemical properties of pomegranate juice, International Journal of Food Science \& Technology, 45(7), pp. 1457-1463

6. Anand P Kulkarni, Somaradhya Mallikarjuna Aradhya, Soundar Divakar, 2004, Isolation and identification of a radical scavenging antioxidant-punicalagin from pith and carpellary membrane of pomegranate fruit, Food Chemistry, 87(4), pp. 551-557

7. Pedro Mena, et.al. 2011. Phytochemical characterisation for industrial use of pomegranate (Punica granatum L.) cultivars grown in Spain, Journal of the Science of Food and Agriculture, 91(10) pp. 1893-1906

8. J. Blasco, S. Cubero, J. Gómez-Sanchís, P. Mira, E. Moltó, 2009, Development of a machine for the automatic sorting of pomegranate (Punica granatum) arils based on computer vision, Journal of Food Engineering, 90(1), pp. 7-34

9. Laura Vázquez-Araújo, et.al. 2010. Sensory and Physicochemical Characterization of Juices Made with Pomegranate and Blueberries, Blackberries, or Raspberries, Journal of Food Science, 75(7), pp. 398-404

10. Gelareh Mousavinejad, et.al. 2009, Identification and quantification of phenolic compounds and their effects on antioxidant activity in pomegranate juices of eight Iranian cultivars, Food Chemistry, 115(4), pp. 12741278

11. Hatice R. Oziyci, Mustafa Karhan, Nedim Tetik and Irfan Turhan, 2013. Effects Of Processing Method And Storage Temperature On Clear Pomegranate Juice Turbidity And Color, Journal of Food Processing and 
Preservation, 37(5), pp. 899-906

12. Suzanne D. Johanningsmeier and G. Keith Harris, 2011. Pomegranate as a Functional Food and Nutraceutical Source, Annual Review of Food Science and Technology, 2, pp. 181-201

13. Kadri Koppel, Erika L Anderson and Edgar Chambers IV, 2014. Influence of processing on pomegranate (Punica granatum L.) juice flavor and aroma, Journal of the Science of Food and Agriculture

14. Shanshan Guo, et.al. 2007, Evaluation of Antioxidant Activity and Preventing DNA Damage Effect of Pomegranate Extracts by Chemiluminescence Method, J. Agric. Food Chem., 2007, 55(8), pp 3134-3140

15. Yanjun Zhang, et.al. 2009, Absence of Pomegranate Ellagitannins in the Majority of Commercial Pomegranate Extracts: Implications for Standardization and Quality Control, J. Agric. Food Chem., 57(16), pp. 7395-7400

16. Anand P. Kulkarni, Somaradhya Mallikarjuna Aradhya, 2005, Chemical changes and antioxidant activity in pomegranate arils during fruit development, Food Chemistry, 93(2), pp. 319-324

17. Hasan Vardin, Mehmet Yasar, 2012, Optimisation of pomegranate (Punica Granatum L.) juice spray-drying as affected by temperature and maltodextrin content, International Journal of Food Science \& Technology, 47(1), pp. 167-176

18. Mira Rosenblat, et.al. 2006, Pomegranate Byproduct Administration to Apolipoprotein E-Deficient Mice Attenuates Atherosclerosis Development as a Result of Decreased Macrophage Oxidative Stress and Reduced Cellular Uptake of Oxidized Low-Density Lipoprotein, J. Agric. Food Chem., 54 (5), pp. 1928-1935

19. H. Hülya Orak, 2009, Evaluation of antioxidant activity, colour and some nutritional characteristics of pomegranate (Punica granatum L.) juice and its sour concentrate processed by conventional evaporation, International Journal of Food Sciences and Nutrition, 60(1), pp. 1-11

20. Salah A Al-Maiman, Dilshad Ahmad, 2002, Changes in physical and chemical properties during pomegranate (Punica granatum L.) fruit maturation, Food Chemistry, 76(4), pp. $437-441$
21. Revital Tzulker, et.al. 2007, Antioxidant Activity, Polyphenol Content, and Related Compounds in Different Fruit Juices and Homogenates Prepared from 29 Different Pomegranate Accessions, J. Agric. Food Chem., 55(23), pp. 9559-9570

22. Walid Elfalleh, et.al. 2011, Fatty acids from Tunisian and Chinese pomegranate (Punica granatum $L$.) seeds, International Journal of Food Sciences and Nutrition 62(3), pp. 200-206

23. Seyed Hossein Mirdehghan, et.al. 2006, Prestorage Heat Treatment To Maintain Nutritive and Functional Properties during Postharvest Cold Storage of Pomegranate, J. Agric. Food Chem., 54 (22), pp. 8495-8500

24. Dobroslawa Bialonska, et.al. 2009, The Effect of Pomegranate (Punica granatum L.) Byproducts and Ellagitannins on the Growth of Human Gut Bacteria, J. Agric. Food Chem., 57(18), pp 8344-8349

25. Walid Elfalleh, et.al. 2009, Physico-chemical properties and DPPH-ABTS scavenging activity of some local pomegranate (Punica granatum) ecotypes, International Journal of Food Sciences and Nutrition 60(2), pp. 197210

26. Hossein Mirsaeedghazi, et.al. 2010, Mathematical modelling of mass transfer in the concentration polarisation layer of flat-sheet membranes during clarification of pomegranate juice, International Journal of Food Science \& Technology, 45(10), pp. 2096-2100

27. Šebojka Komorsky-Lovrić, Ivana Novak, 2011, Abrasive Stripping Square-Wave Voltammetry of Blackberry, Raspberry, Strawberry, Pomegranate, and Sweet and Blue Potatoes, Journal of Food Science, 76(6), pp. 916-920

28. Oluwafemi James Caleb, Umezuruike Linus Opara, Corli R. Witthuh, 2012, Modified Atmosphere Packaging of Pomegranate Fruit and Arils: A Review, Food and Bioprocess Technology, 5(1), pp. 15-30

29. Neslihan Alper, K. Savaş Bahçeci and Jale Acar, 2005, Influence Of Processing And Pasteurization On Color Values And Total Phenolic Compounds Of Pomegranate Juice, Journal of Food Processing and Preservation, 29(5-6), pp. 357-368

30. Yunfeng Li, Changjiang Guo, Jijun Yang, Jingyu Wei, Jing Xu, Shuang Cheng, 2006, Evaluation of antioxidant properties of pomegranate peel extract in comparison with 
pomegranate pulp extract, Food Chemistry, 96(2), pp. 254-260

31. Oluwafemi J. Caleb, et.al. 2012. Modeling the Effect of Time and Temperature on Respiration Rate of Pomegranate Arils (cv. "Acco" and 'Herskawitz'), Journal of Food Science, 77(4), pp. 80-87

32. Begoña Cerdá, José J. Cerón, Francisco A. Tomás-Barberán and Juan Carlos Espín, 2003, Repeated Oral Administration of High Doses of the Pomegranate Ellagitannin Punicalagin to Rats for 37 Days Is Not Toxic, J. Agric. Food Chem., 51 (11), pp. 34933501

33. P.S. Negi, G.K. Jayaprakasha, B.S. Jena, 2003, Antioxidant and antimutagenic activities of pomegranate peel extracts, Food Chemistry, 80(3), pp. 393-397

34. Jingjing Lu, Qipeng Yuan, 2008. A New Method For Ellagic Acid Production From Pomegranate Husk, Journal of Food Process Engineering, 31(4), pp. 443-454

35. S. Naz, R. Siddiqi, et.al. 2007. Antibacterial Activity Directed Isolation of Compounds from Punica granatum, Journal of Food Science, 72(9), pp. 341-345

36. Medeni Maskan, 2006. Production of pomegranate (Punica granatum L.) juice concentrate by various heating methods: colour degradation and kinetics, Journal of Food Engineering, 72(3), 218-224

37. Guangmin Liu, Xiang Xu, Qinfeng Hao, Yanxiang Gao, 2009, Supercritical $\mathrm{CO}_{2}$ extraction optimization of pomegranate (Punica granatum L.) seed oil using response surface methodology, LWT - Food Science and Technology, 42(9), pp. 1491-1495

38. S. Madrigal, et.al. 2009, Pomegranate (Punica granatum) supplements: Authenticity, antioxidant and polyphenol composition, Journal of Functional Foods, 1(3), pp. 324329

39. Vidhan Jaiswala, et.al. 2010, Anthocyanins and polyphenol oxidase from dried arils of pomegranate (Punica granatum L.), Food Chemistry, 118(1), pp. 11-16

40. Walid Elfalleh, et.al. 2011. Antioxidant Capacities of Phenolic Compounds and Tocopherols from Tunisian Pomegranate (Punica granatum) Fruits, Journal of Food Science, 76(5), pp. 707-713

41. Nuria Martí, et.al. 2002, Influence of storage temperature and ascorbic acid addition on pomegranate juice, Journal of the Science of Food and Agriculture, 82(2), pp. 217-221

42. Navindra P. Seeram, et.al.
2007, Pomegranate Ellagitannin-Derived Metabolites Inhibit Prostate Cancer Growth and Localize to the Mouse Prostate Gland, J. Agric. Food Chem., 55(19), pp. 7732-7737

43. C. T. Du, P. L. Wang and F. J. Francis, 1975, Anthocyanins of Pomegranate, Punica Granatum, Journal of Food Science, 40(2), pp. 417-418

44. Zheng Li, et.al. 2011, Fabrication of nanoparticles using partially purified pomegranate ellagitannins and gelatin and their apoptotic effects, Molecular Nutrition \& Food Research, 55(7), pp. 1096-1103

45. Ahmet Kaya, Nesli Sözer, 2005. Rheological behaviour of sour pomegranate juice concentrates (Punica granatum L.), International Journal of Food Science \& Technology, 40(2), pp. 223-227

46. A Pérez-Vicente, P Serrano, P. Abellán, C. García-Viguera, 2004, Influence of packaging material on pomegranate juice colour and bioactive compounds, during storage, Journal of the Science of Food and Agriculture, 84(7), pp. 639-644

47. Paz Robert, Tamara Gorena, Nalda Romero, Elena Sepulveda, Jorge Chavez and Carmen Saenz, 2010. Encapsulation of polyphenols and anthocyanins from pomegranate (Punica granatum) by spray drying, International Journal of Food Science \& Technology, 45(7), pp. 1386-1394

48. P Melgarejo and F Artés, 2000, Total lipid content and fatty acid composition of oilseed from lesser known sweet pomegranate clones, Journal of the Science of Food and Agriculture, 80(10), pp. 14521454

49. Basappa M. Naveena, et.al. 2008. Antioxidant activity of pomegranate rind powder extract in cooked chicken patties, International Journal of Food Science \& Technology, 43(10), pp. 1807-1812

50. Mehdi Mohagheghi, et.al. 2011, Pomegranate seed oil as a functional ingredient in beverages, European Journal of Lipid Science and Technology, 113(6), pp. 730-736

51. Arpita Basu, Kavitha Penugonda, 2009. Pomegranate juice: a heart-healthy fruit juice, Nutrition Reviews, 67(1), pp. 49-56

52. Keith R. Martin, et.al. 2009. Development of a novel pomegranate standard and new method for the quantitative measurement of pomegranate polyphenols, Journal of the Science of Food and Agriculture, 
89(1) pp. 157-162

\section{SCIENCE BOTANY}

1. D. Narzary, T. S. Rana, S. A. Ranade, 2010, Genetic diversity in inter-simple sequence repeat profiles across natural populations of Indian pomegranate (Punica granatum L.), Plant Biology, 12(5), pp. 806-813

2. F. Peduto Hand, 2014, Pomegranate (Punica granatum) in the United States, APS Journal, 98(6), pp. 853

3. L. Vázquez-Araújo, et.al. 2011, Instrumental and sensory aroma profile of pomegranate juices from the USA: differences between fresh and commercial juice, Flavour and Fragrance Journal, 26(2), pp. 129-138

4. E. Bayhana, S. ÖLmez-Bayhanb, M. R. Ulusoyc, and J. K. Brown, 2005. Effect of Temperature on the Biology of Aphis punicae (Passerini) (Homoptera: Aphididae) on Pomegranate, Environmental Entomology, pp. 22-26

5. Gary Sassano, Paul Sanderson, Johan Franx, Pascal Groot, Jeroen van Straalen and Josep Bassaganya-Riera, 2009. Analysis of pomegranate seed oil for the presence of jacaric acid, Journal of the Science of Food and Agriculture, 89(6), pp. 1046-1052

6. Seyed Hossein Mirdehghan, Majid Rahemi, 2007. Seasonal changes of mineral nutrients and phenolics in pomegranate (Punica granatum L.) fruit, Scientia Horticulturae, 111(2), pp. 120-127

7. Rania Jbira, et.al. 2008, Characterization of Tunisian pomegranate (Punica granatum L.) cultivars using amplified fragment length polymorphism analysis, Scientia Horticulturae, 115(3), pp. 231-237

8. Soumendra K. Naik, Pradeep K. Chand, 2003, Silver nitrate and amino ethoxyvinyl glycine promote in vitro adventitious shoot regeneration of pomegranate (Punica granatum L.), Journal of Plant Physiology, 160(4), pp. 423-430

9. Salaheddin M. Elyatem, Adel A. Kader, 1984, Post-harvest physiology and storage behaviour of pomegranate fruits, Scientia Horticulturae, 24(3-4), pp. 287-298

10. A. Bucchini, et.al. 2006, Antioxidant activity of Punica granatum fruits, Fitoterapia, 77(4), pp. 310-312

11. Aylin Altan, Medeni Maskan, 2005. Rheological Behavior Of Pomegranate (Punica Granatum L.) Juice And Concentrate, Journal of Texture Studies, 36(1), pp. 68-77
12. Zhaohe Yuan, Yanlei Yin, Jianlu Qu, Liqin Zhu, Yun Li, 2007, Population Genetic Diversity in Chinese Pomegranate (Punica granatum L.) Cultivars Revealed by Fluorescent-AFLP Markers, Journal of Genetics and Genomics, 34(12), pp. 10611071

13. Ru-Feng Wang, et.al. 2004. Bioactive Compounds from the Seeds of Punica granatum (Pomegranate), J. Nat. Prod., 67(12), pp. 2096-2098

14. F. Khoshnam, et.al. 2007, Mass modeling of pomegranate (Punica granatum L.) fruit with some physical characteristics, Scientia Horticulturae, 114(1), pp. 21-26

15. Andjarikmawati, et.al. 2005. Germination and growth of pomegranate (Punica granatumL.) with the treatment of indol acetic acid and gibberellic acid. Jurnal Biosmart. 7(2), pp. 91-94

16. Soumendra K Naik, et.al. 2000, High frequency axillary shoot proliferation and plant regeneration from cotyledonary nodes of pomegranate (Punica granatum L.), Scientia Horticulturae, 85(4), pp. 261-270

17. G.K. Aseri, et.al. 2008, Biofertilizers improve plant growth, fruit yield, nutrition, metabolism and rhizosphere enzyme activities of Pomegranate (Punica granatum L.) in Indian Thar Desert, Scientia Horticulturae, 117(2), pp. 130-135

18. Rufeng Wanga, et.al. 2006, Constituents of the flowers of Punica granatum. Fitoterapia, 77(7-8), pp. 534-537

19. S. Sudheesh, N.R. Vijayalakshmi, 2005, Flavonoids from Punica granatum-potential anti-peroxidative agents, Fitoterapia, 76(2), pp. 181-186

20. A. Sarkhosh, Z. Zamani, R. Fatahi, A. Ebadi, 2006, RAPD markers reveal polymorphism among some Iranian pomegranate (Punica granatum L.) genotypes, Scientia Horticulturae, 111(1), 2006, pp. 24-29

21. J.J. Martíneza, et.al. 2006, Seed characterisation of five new pomegranate (Punica granatum L.) varieties, Scientia Horticulturae, 110(3), pp. 241-246

22. Hajimahmoodi M. et.al. 2008, Antioxidant properties of peel and pulp hydro extract in ten Persian pomegranate cultivars, Pakistan Journal of Biological Sciences, 11(12), pp. 1600-1604

23. G. A. Bardas, G. D. Tzelepis, L. Lotos, and G. S. Karaoglanidis, 2009, First Report 
of Penicillium glabrum Causing Fruit Rot of Pomegranate (Punica granatum) in Greece, APS Journal, 93(12), pp. 1347 BIO-MEDICAL

1. B. Balbir-Gurman A, Fuhrman B, Braun-Moscovici Y, Markovits D, Aviram M, 2011, Consumption of pomegranate decreases serum oxidative stress and reduces disease activity in patients with active rheumatoid arthritis: a pilot study. The Israel Medical Association Journal: IMAJ 13(8), pp. 474-479

2. Mira Rosenblat, Tony Hayek, Michael Aviram, 2006, Anti-oxidative effects of pomegranate juice (PJ) consumption by diabetic patients on serum and on macrophages, Atherosclerosis, 187(2), pp. 363-371

3. Bhadbhade SJ, Acharya AB, Rodrigues SV, Thakur SL, 2011, The antiplaque efficacy of pomegranate mouthrinse. Quintessence International, 42(1), pp. 29-36

4. Vaqar M. Adhami,Hasan Mukhtar, 2006, Polyphenols from green tea and pomegranate for prevention of prostate cancer, Free Radical Research, 40(10), pp. 1095-1104

5. Allan J. Pantuck, et.al. 2006, Phase II Study of Pomegranate Juice for Men with Rising Prostate-Specific Antigen following Surgery or Radiation for Prostate Cancer, Clin. Cancer Res, 12, pp. 4018

6. F Lei, X N Zhang, et.al. 2007, Evidence of anti-obesity effects of the pomegranate leaf extract in high-fat diet induced obese mice, International Journal of Obesity31, pp. 1023-1029

7. Alexey V. Sorokin, et.al. 2006, Rhabdomyolysis Associated With Pomegranate Juice Consumption, The American Journal of Cardiology, 98(5), pp. 705-706

8. Yuhao Li, Yanfei Qi, Tom H. W. Huang, Johji Yamahara and Basil D. Roufogalis, 2008, Pomegranate flower: a unique traditional antidiabetic medicine with dual PPAR-a/- $\gamma$ activator properties, Diabetes, Obesity and Metabolism, 10(1), pp. 10-17

9. Michael D. Sumner, PhD, et.al. 2005, Effects of Pomegranate Juice Consumption on Myocardial Perfusion in Patients With Coronary Heart Disease, The American Journal of Cardiology, 96(6), pp. 810-814

10. Susan R Sturgeon, Alayne G Ronnenberg, 2010, Pomegranate and breast cancer: possible mechanisms of prevention, Nutrition Reviews, 68(2), pp. 122-128

11. Gaffari Türk, et.al. 2008, Effects of pomegranate juice consumption on sperm quality, spermatogenic cell density, antioxidant activity and testosterone level in male rats, Clinical Nutrition, 27(2), pp. 289296

12. Lisbeth A. Pacheco-Palencia, et.al. 2008, Protective Effects of Standardized Pomegranate (Punica granatum L.) Polyphenolic Extract in Ultraviolet-Irradiated Human Skin Fibroblasts, J. Agric. Food Chem., 56 (18), pp. 8434-8441

13. Michael Aviram, et.al. 2004, Pomegranate juice consumption for 3 years by patients with carotid artery stenosis reduces common carotid intima-media thickness, blood pressure and LDL oxidation, Clinical Nutrition, 23(3), pp. 423-433

14. Mehta, R. Lansky, 2004. Breast cancer chemopreventive properties of pomegranate (Punica granatum) fruit extracts in a mouse mammary organ culture, European Journal of Cancer Prevention, 13(4), pp. 345-348

15. Farrukh Afaq, Mohammad Abu Zaid, Naghma Khan, Mark Dreher and Hasan Mukhtar, 2009. Protective effect of pomegranate-derived products on UVBmediated damage in human reconstituted skin, Experimental Dermatology, 18(6), pp. 553-561

16. Lynn S. Adams, et.al. 2006, Pomegranate Juice, Total Pomegranate Ellagitannins, and Punicalagin Suppress Inflammatory Cell Signaling in Colon Cancer Cells, J. Agric. Food Chem., 54(3), pp. 980-985

17. Susanne U. Mertens-Talcott, et.al. 2006, Absorption, Metabolism, and Antioxidant Effects of Pomegranate (Punica granatum L.) Polyphenols after Ingestion of a Standardized Extract in Healthy Human Volunteers, J. Agric. Food Chem., 54(23), pp. 8956-8961

18. David Heber, et.al. 2007. Safety and Antioxidant Activity of a Pomegranate Ellagitannin-Enriched Polyphenol Dietary Supplement in Overweight Individuals with Increased Waist Size, J. Agric. Food Chem., 55(24), pp 10050-10054

19. Hye Min Park, et.al. 2010. Extract of Punica granatum inhibits skin photo aging induced by UVB irradiation, International Journal of Dermatology, 49(3), pp. 276-282

20. Priyanka Bagria, Mohd. Alia, Vidhu Aeria, Shahnaz Sultana, 2009. Antidiabetic effect of Punica granatum flowers: Effect on 
hyperlipidemia, pancreatic cells lipid peroxidation and antioxidant enzymes in experimental diabetes, Food and Chemical Toxicology, 47(1), pp. 50-54

21. Hamendra Singh Parmar and Anand Kar. 2008. Medicinal Values of Fruit Peels from Citrus sinensis, Punica granatum, and paradisiaca with Respect to Alterations in Tissue Lipid Peroxidation and Serum Concentration of Glucose, Insulin, and Thyroid Hormones, Journal of Medicinal Food, 11(2), pp. 376-381

22. A Robert Neurath, Nathan Strick, YunYao Li1 and Asim K Debnath, 2004, Punica granatum (Pomegranate) juice provides an HIV-1 entry inhibitor and candidate topical microbicide, BMC Infectious Diseases, 4(41)

23. Hamendra Singh Parmar, Anand Kar, 2007, Protective role of Citrus sinensis, Musa paradisiaca and Punica granatum peels against diet-induced atherosclerosis and thyroid dysfunctions in rats, Nutrition Research, 27(11), pp. 710-718

24. Mehran Haidari, Muzammil Ali, Samuel Ward Casscells III, Mohammad Madjid, 2009, Pomegranate (Punica granatum) purified polyphenol extract inhibits influenza virus and has a synergistic effect with oseltamivir, Phytomedicine, 16(12), pp. 1127-1136

25. Ines Ksentini, et.al. 2010, Naturally occurring egg parasitoids of the genus Trichogramma (Hymenoptera: Trichogrammatidae) in a pomegranate orchard in Tunisia, Entomological Science, 13(1), pp. 99-106

26. K. N. Chidambara Murthy, et.al. 2004, Study on Wound Healing Activity of Punica granatum Peel, Journal of Medicinal Food. 7(2), pp. 256-259.

27. Jurenka JS, 2008. Therapeutic applications of pomegranate (Punica granatum L.): A review. Alternative Medicine Review :A Journal of Clinical Therapeutic 13(2), pp. 128-144

28. A. Robert Neurath, et.al. 2005. Punica granatum (Pomegranate) Juice Provides an HIV-1 Entry Inhibitor and Candidate Topical Microbicide, Annals of the New York Academy of Sciences, 1056 Natural Products and Molecular Therapy, pp. 311-327

29. Aviram M, et.al. 2002. Pomegranate juice flavonoids inhibit low-density lipoprotein oxidation and cardiovascular diseases: studies in atherosclerotic mice and in humans. Drugs Under Experimental and Clinical Research, 28(2-3), pp. 49-62

30. Sigrun Chrubasik-Hausmann, Christian Vlachojannis and Benno Zimmermann, 2014, Pomegranate Juice and Prostate Cancer: Importance of the Characterisation of the Active Principle, Phytotherapy Research, 28(11), pp. 1676-1678

31. C P Forest1, H Padma-Nathan1 and H R Liker, 2007, Efficacy and safety of pomegranate juice on improvement of erectile dysfunction in male patients with mild to moderate erectile dysfunction: a randomized, placebo-controlled, double-blind, cross over study, International Journal of Impotence Research, 19, pp. 564-567

32. Michael Aviram, Leslie Dornfeld, 2005. Pomegranate juice consumption inhibits serum angiotensin converting enzyme activity and reduces systolic blood pressure, Atherosclerosis, 158(1), pp. 195-198

33. Gaig P, Botey J, et.al. 1992, Allergy to pomegranate (Punica granatum), Journal of Investigational Allergology \& Clinical Immunology, 2(4), pp. 216-218

34. R. Valsecchi, 1998, Immediate contact hypersensitivity to pomegranate, Contact Dermatitis, 38(1), pp. 44-45

35. Zuarida Mohyin, Buah Delima Kurangkan Risiko Sakit Jantung, majalah Al-Islam, Februari 2001

36. Arshi Malik, Farrukh Afaq, Sami Sarfaraz, Vaqar M. Adhami, Deeba N. Syed, and Hasan Mukhtar, Pomegranate fruit juice for chemoprevention and chemotherapy of prostate cancer, Proceedings of the National Academy of Sciences of the United States of America, October 11, 2005, vol. 102, no. 41

37. Nor Azma Hannah Mazlan, 2004. Cytoprotection effects by honey alone or in combination with methanol extract of punica granatum $L$. and ethanol extract of nigella sativa L. on ethanol-induced gastric damage in rats. Disertasi Sarjana. Jabatan Perubatan Molekul, Fakulti Perubatan, Kuala Lumpur: Universiti Malaya

38. Ade Indah Pratiwi, 2014. Manfaat Berkumur Sari Buah Delima Merah (Punica Granatum) Terhadap Penurunan akumulasi Plak Gigi, Skripsi Sarjana Kedokteran Gigi. Fakultas Kedokteran Gigi Universitas Mahasaraswati Denpasar

39. Sugianto, Nanik Lidyawati. 2011. 
Pemberian Jus Delima Merah (Punica Granatum) Dapat Meningkatkan Kadar Glutation Peroksidase Darah Pada Mencit (Mus Musculus) Dengan Aktivitas Fisik Maksimal. Tesis: Program Magister, Program Studi Ilmu Biomedik, Program Pascasarjana. Denpasar: Universitas Udayana

40. عزت فارس, الرمان: غداء ودواء, ماجستير تغذية الإنسان, قسم التغذية, كلية الصيدلة والعلوم الطبية, جامعة البترا الأردنية

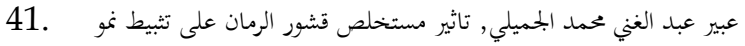

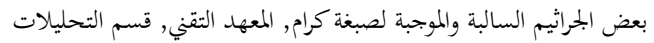

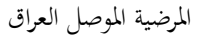

\section{BIO-CHEMICAL}

1. Ellen Hornung, Christian Pernstich and Ivo Feussner, 2002, Formation of conjugated $\Delta^{11} \Delta^{13}$-double bonds by $\Delta^{12}$ linoleic acid (1,4)-acyl-lipid-desaturase in pomegranate seeds, European Journal of Biochemistry, 269(19), pp. 4852-4859

2. Arzu Akpinar-Bayizit, 2010, Analysis of Mineral Content in Pomegranate Juice by ICP-OES, Asian J. Chem., 22(8), pp 65426546

3. Michael Aviram, et.al. 2008, Pomegranate Phenolics from the Peels, Arils, and Flowers Are Antiatherogenic: Studies in Vivo in Atherosclerotic Apolipoprotein E-Deficient $\left(E^{0}\right)$ Mice and in Vitro in Cultured Macrophages and Lipoproteins, J. Agric. Food Chem., 56 (3), pp. 1148-1157

4. Dobroslawa Bialonska, et.al. 2009, Intestinal Microbial Metabolites of Pomegranate Ellagitannins, Exhibit Potent Antioxidant Activity in a Cell-Based Assay, J. Agric. Food Chem., 57(21), pp. 1018110186

5. Deeba N. 2006. Potochemopreventive Effect of Pomegranate Fruit Extract on UVA-mediated Activation of Cellular Pathways in Normal Human Epidermal Keratinocytes, Photochemistry and Photobiology, 82(2), pp. 398-405

6. Farrukh Afaq, etal. 2005, Pomegranate Fruit Extract Modulates UV-B-mediated Phosphorylation of Mitogen-activated Protein Kinases and Activation of Nuclear Factor Kappa B in Normal Human Epidermal Keratinocytes, Photochemistry and Photobiology, 81(1), pp. 38-45

7. Navindra P. Seeram, et.al. 2005. In vitro antiproliferative, apoptotic and antioxidant activities of punicalagin, ellagic acid and a total pomegranate tannin extract are enhanced in combination with other polyphenols as found in pomegranate juice, The Journal of Nutritional Biochemistry, 16(6), pp. 360-367

8. Mohammad Abu Zaid, et.al. 2007. Inhibition of UVB-mediated Oxidative Stress and Markers of Photoaging in Immortalized $\mathrm{HaCaT}$ Keratinocytes by Pomegranate Polyphenol Extract POMx, Photochemistry and Photobiology, 83(4), pp. 882-888

9. Farrukh Afaq, Naghma Khan, Deeba N. Syed and Hasan Mukhtar, 2010. Oral Feeding of Pomegranate Fruit Extract Inhibits Early Biomarkers of UVB Radiationinduced Carcinogenesis in SKH-1 Hairless Mouse Epidermis, Photochemistry and Photobiology, 86(6), pp. 1318-1326

10. Danny A van Elswijk, Uwe P Schobel, Ephraim P Lansky, Jan van der Greef, 2004, Rapid dereplication of estrogenic compounds in pomegranate (Punica granatum) using on-line biochemical detection coupled to mass spectrometry, Phytochemistry, pp. 233-241

11. Takashi Tanaka, et.al, 1985. Punicafolin, an ellagitannin from the leaves of Punica granatum, Phytochemistry, 24 (9), pp. 2075-2078

12. Ulrike A. Fischer, Reinhold Carle, Dietmar, R. Kammerer, 2011. Identification and quantification of phenolic compounds from pomegranate (Punica granatum L.) peel, mesocarp, aril and differently produced juices by HPLC-DADESI/MSn, Food Chemistry, 127(2), pp. 807-821

13. Mahmoud A.M. Nawwar, Sahar A.M. Hussein, Irmgard Merfort, 1994, Leaf phenolics of Punica granatum, Phytochemistry, 37(4), pp. 1175-1177

14. Ismail Celik, Atilla Temur, Ismail Isik, 2009. Hepatoprotective role and antioxidant capacity of pomegranate (Punica granatum) flowers infusion against trichloroacetic acidexposed in rats, Food and Chemical Toxicology, 47(1), pp. 145-149

15. Sezai Ercislia, Guleray Agarb, et.al. 2007. Interspecific variability of RAPD and fatty acid composition of some pomegranate cultivars (Punica granatum L.) growing in Southern Anatolia Region in Turkey, Biochemical Systematics and Ecology, 35(11), pp. 764-769

16. Meenakshi Shukla, et.al. 2008, Bioavailable constituents/metabolites of pomegranate (Punica granatum L) preferentially inhibit COX2 activity ex vivo and IL-1beta-induced 
$P G E_{2}$ production in human chondrocytes in vitro, Journal of Inflammation, 5(9)

17. Heryani. 2010. Aktivitas fraksi polifenol buah delima (Punica granatum l.) Terhadap peroksidasi lipid darah Tikus yang diinduksi parasetamol. Departemen biokimia. Fakultas matematika dan ilmu pengetahuan alam Bogor: Institut Pertanian Bogor

18. Apriliana, Dian. 2010. Aktivitas Hepatoproteksi Ekstrak Polifenol Buah Delima (Punica granatum l.) Terhadap Tikus Putih yang Diinduksi Parasetamol. Departemen Biokimia. Fakultas Matematika dan Ilmu Pengetahuan Alam. Bogor: Institut Pertanian Bogor

19. Sayed A.A El-Toumya b, Hans W Rauwald, 2002, Two ellagitannins from Punica granatum heartwood, Phytochemistry, 61(80, pp. 971-974

20. Yasuko Noda, Takao Kaneyuki, Akitane Mori and Lester Packer, 2002, Antioxidant Activities of Pomegranate Fruit Extract and Its Anthocyanidins: Delphinidin, Cyanidin, and Pelargonidin, J. Agric. Food Chem., 50(1), pp. 166-171

21. Mahmoud A.M. Nawwar, Sahar A.M. Hussein, Irmgard Merforta, 1994. NMR spectral analysis of polyphenols from Punica granatum, Phytochemistry, 36(3), pp. 793798

22. Gurpreet

Kaura, Zoobi Jabbarb, Mohammad Athara, M. Sarwar Alam, 2006, Punica granatum (pomegranate) flower extract possesses potent antioxidant activity and abrogates Fe-NTA induced hepatotoxicity in mice, Food and Chemical Toxicology, 44(7), pp. 984-993

23. María I. Gil, Francisco A. TomásBarberán, Betty Hess-Pierce, Deirdre M. Holcroft and Adel A. Kader, 2000, Antioxidant Activity of Pomegranate Juice and Its Relationship with Phenolic Composition and Processing, J. Agric. Food Chem., 48 (10), pp. 4581-4589

24. Farrukh Afaq, et.al. 2005. Anthocyaninand hydrolyzable tannin-rich pomegranate fruit extract modulates MAPK and NF- $k B$ pathways and inhibits skin tumorigenesis in $C D-1$ mice, International Journal of Cancer, 113(3), pp. 423-433

25. Ali Tehranifara, et.al. 2010, Investigation of physico-chemical properties and antioxidant activity of twenty Iranian pomegranate (Punica granatum L.) cultivars, Scientia Horticulturae, 126(2), pp. 180185

26. Amit Bhatnagara, A.K. Minocha, 2010, Biosorption optimization of nickel removal from water using Punica granatum peel waste, Colloids and Surfaces B: Biointerfaces, 76(2), pp. 544-548

27. K. Koppel and E. Chambers, 2010, Development and Application Of A Lexicon To Describe The Flavor of Pomegranate Juice, Journal of Sensory Studies, 25(6), pp. 819837

28. Hoang Ngoc Ai Tran, et.al. 2010, Pomegranate (Punica granatum) Seed Linolenic Acid Isomers: ConcentrationDependent Modulation of Estrogen Receptor Activity, Endocrine Research, 35(1), pp. 116

29. Ahmed A. Tayel and Wael F. El-Tras, 2010. Anticandidal activity of pomegranate peel extract aerosol as an applicable sanitizing method, Mycoses, 53(2), pp. 117-122

30. E.-S.Z. El-Ashtoukhy, N.K. Amin, O. Abdelwahab, 2008. Removal of lead (II) and copper (II) from aqueous solution using pomegranate peel as a new adsorbent, Desalination, 223(1-3), pp. 162-173

31. Navindra P. Seeram, Rupo Lee, David Heber, 2004, Bioavailability of ellagic acid in human plasma after consumption of ellagitannins from pomegranate (Punica granatum L.) juice, Clinica Chimica Acta, 348(1-2), pp. 63-68

32. Qingquan Liu, et.al. 2011, A simple route to prepare pomegranate-like polystyrenebased microspheres with high porosity, Polymer International, 60(9), pp. 12871290

33. N. Seeram, R. Lee, M. Hardy, D. Heber, 2005, Rapid large scale purification of ellagitannins from pomegranate husk, a byproduct of the commercial juice industry, Separation and Purification Technology, 41(1), pp. 49-55

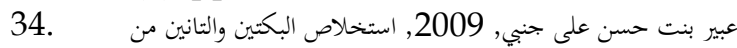

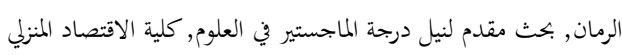

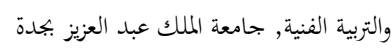

35. زهراء يوسف خضير, تأثير بعض العوامل الفيزياوية والكيمياوية المعزول من ثمار الطماطة في الأسواق المحلية لمحافظة النجف الاشرف, قسم 
علوم الحياة, كلية العلوم جامعة الكوفة

\section{MICROBIOLOGY}

1. Suhad A. Ahmed, Nagham H. Abood, Dr. Abbas A. Al-Janabi, 2013, Antimicrobial Effect of Pomegranate Peel Extract on Some Pathogenic Microorganisms, Eng. \& Tech. Journal, 31(3)

2. Soumendra K. Naik, et.al. 1999, In vitro propagation of pomegranate (Punica granatum L. cv. Ganesh) through axillary shoot proliferation from nodal segments of mature tree, Scientia Horticulturae, 79(34), pp. 175-183

3. Sandika, Bayu, Raharjo dan Nur Ducha. 2012. Pengaruh Pemberian Air Rebusan Akar Delima (Punica granatum L.) terhadap Mortalitas Ascaris suum Goesze. Secara In Vitro. Jurusan Biologi, Fakultas Matematika dan Ilmu Pengetahuan Alam. Universitas Negeri Surabaya. Lentera Bio, 1(2), pp. $81-86$

4. B. Cerdá, et.al. 2004, Ellagitannins from pomegranate juice are metabolised into bioavailable but poor antioxidant hydroxy$6 \mathrm{H}$-dibenzopyran-6- one derivatives by the colonic microflora of healthy humans, European Journal of Nutrition, 43(4), pp 205-220

5. Veeramuthu Duraipandiyan, Muniappan Ayyanar and Savarimuthu Ignacimuthu, 2006, Antimicrobial activity of some ethnomedicinal plants used by Paliyar tribe from Tamil Nadu, India, BMC Complementary and Alternative Medicine , 6(35)

6. E.A. Hayounia, et.al. 2011, Hydroalcoholic extract based-ointment from Punica granatum $L$. peels with enhanced in vivohealing potential on dermal wound, Phytomedicine, 18(15), pp. 976-984

7. Mario Dell Agli, et.al. 2010, Ellagitannins of the fruit rind of pomegranate (Punica granatum) antagonize in vitro the host inflammatory response mechanisms involved in the onset of malaria, Malaria Journal, $9(208)$

8. Chia-Jung Leea, et.al. 2010, Antiinflammatory effects of Punica granatum Linne in vitro and in vivo, Food Chemistry, 118(2), pp. 315-322

9. Thelma de B. et.al. 2002, Antimicrobial Ellagitannin of Punica granatum Fruits, Journal of the Brazilian Chemical Society, 13(5)

10. Zhang J, Zhan B, Yao X, Gao Y, Shong J,
1995, Antiviral activity of tannin from the pericarp of Punica granatum L. against genital Herpes virus in vitro, China Journal of Chinese Materia Medica, 20(9), pp. 556-576

11. N.S. Al-Zoreky, 2009. Antimicrobial activity of pomegranate (Punica granatum L.) fruit peels, International Journal of Food Microbiology, 134(3), pp. 244-248

12. R. P. Singh, K. N. Chidambara Murthy and G. K. Jayaprakasha, 2001, Studies on the Antioxidant Activity of Pomegranate (Punica granatum) Peel and Seed Extracts Using in Vitro Models, J. Agric. Food Chem., 50(1), pp. 81-86

13. Kotamballi N. Chidambara Murthy, et.al. 2002. Studies on Antioxidant Activity of Pomegranate (Punica granatum) Peel Extract Using in Vivo Models, J. Agric. Food Chem., 50(17), pp. 4791-4795

14. Soumendra K. Naik, Pradeep K. Chand, 2006, Nutrient-alginate encapsulation of in vitro nodal segments of pomegranate (Punica granatum L.) for germplasm distribution and exchange, Scientia Horticulturae, 108(3), pp. 247-252

15. Sweetie R. Kanatt, et.al. 2010. Antioxidant and antimicrobial activity of pomegranate peel extract improves the shelf life of chicken products, International Journal of Food Science \& Technology, 45(2), pp. 216-222

16. Antonio Pérez-Vicente, Angel GilIzquierdo, Cristina García-Viguera, 2002, In Vitro Gastrointestinal Digestion Study of Pomegranate Juice Phenolic Compounds, Anthocyanins, and Vitamin C, J. Agric. Food Chem., 50(8), pp. 23082312

17. S. Rout, R. Banerjee, 2007, Free radical scavenging, anti-glycation and tyrosinase inhibition properties of a polysaccharide fraction isolated from the rind from Punica granatum, Bioresource Technology, 98(16), pp. 3159-3163

18. Purwantini, Indah dan Subagus Wahyuono. Isolation and identification of antifungal (candida albicans) compound from the hull of delima fruits (punica granatum). Majalah Farmasi Indonesia. UGM Yokyakarta

19. Wirawan, Hans Ceisar. 2008. Pengaruh ekstrak delima putih (punica granatum, l) terhadap proliferasi alur sel leukimia (thp-1) secara in Vitro. Skripsi. Fakultas Teknologi Pertanian. Bogor. Institut 
Pertanian Bogor

20. Nauli, Rizki Rahma. 2010. Pengaruh Pemberian Ekstrak Kulit Buah Delima Putih (Punica Granatum Linn) Dan Ketokonazol 2\% Terhadap Pertumbuhan Candida Albicanssecara In Vitro Pada Kandidiasis Vulvovaginalis. Skripsi. Program Pendidikan Sarjana Kedokteran, Fakultas Kedokteran. Semarang: Universitas Diponegoro

\section{SCOPE OF RESEARCH AND DISCUSSION ON POMEGRANATE}

Based on the study of the pomegranate classification, analysis of the results are as follows;

Table 1.

Classification of research area on pomegaranate

\begin{tabular}{|l|c|c|}
\hline & Frequency & $\begin{array}{c}\text { Valid } \\
\text { Percent }\end{array}$ \\
\hline Valid Environmental Education (Flora) & 10 & 4.7 \\
Islamic Education & 11 & 5.2 \\
Pharmacology & 19 & 9.0 \\
Nutritional Science & 52 & 24.6 \\
Science Botany & 23 & 10.9 \\
Bio-Medical & 41 & 19.4 \\
Bio-Chemical & 35 & 16.6 \\
Microbiology & 20 & 9.5 \\
Jumlah & 211 & 100.0 \\
\hline
\end{tabular}

Bldang Penyelldlkan

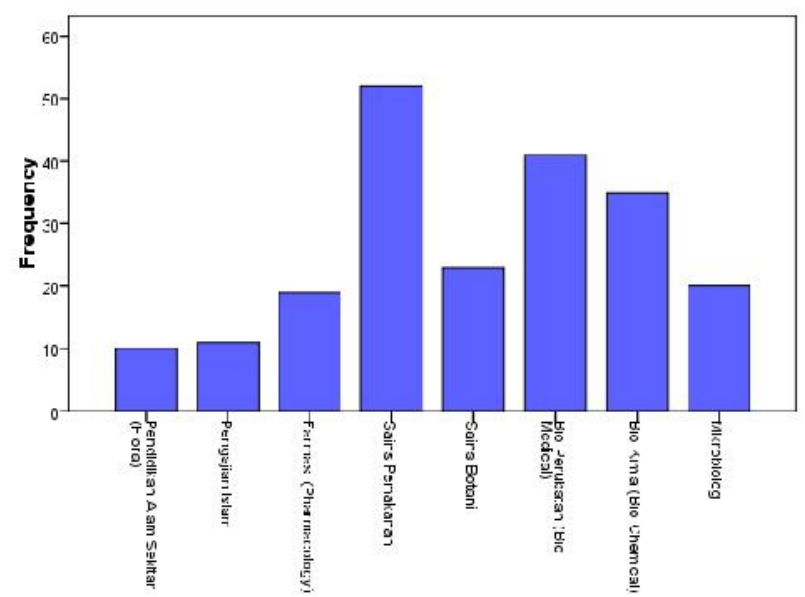

Research on the method of analysis conducted in the previous studies found that most studies on pomegranate done on a scientific analysis (laboratory studies). Studies on aspects of science has been divided into six areas. Focus areas include scientific discussion of pomegranate covered in the aspect of Pharmacy, Nutritional Science,Science Botany, Bio-Medical, Bio-Chemical and Microbiology. Only one field of study that focuses on the analysis of Islam focusing on Islamic Education.

Additional fields of Environmental Education (Flora) are also included by researchers to collect data and find a results on plants that contain pomegranate. Comparative evaluation of research found that a total of 188 kinds of studies involves the study of the scientific aspects compared to only 11 studies based on Islam (Islamic Education) and 10 studies based on environmental education. Thus, this proves the scientific study of pomegranate is well known by researcher.

Pomegranate is a fruit that has attracted researchers from around the world in which all components of the pomegranate has its own significance for the research analysis to identify its benefits and interests. This includes the skin, fruit, juice, and seed to produce extracts of pomegranate.

Referring to the study of pomegranate from the perspective of Islamic studies, it clearly shows the lack of specific research material concerning this fruit. The best study discusses in detail about the pomegranate from the point of view of religion and science is a article in journal entitled "Punica Granatum Bicara Al-Quran Al-Hadith Dan Sains Perubatan Moden" (Punica Granatum From Al-Quran, Al-Hadith and Modern Medical Science's Point of View) by Dr. Munirah Abd 
Razzak and book written by Dr. Zaid bin Muhammad al-Rummani entitled "Penawar Dalam Buah Delima, Makanan Syurga dan Ubat (Antidote In Pomegranate, Food and Medication of Heaven).

More than that, studies of a pomegranate are only discussed in general view with a summary of the usefulness or efficacy of pomegranate in books or medical research focuses on Tibb al-Nabawi. Among the examples is book Tibb al-Nabawi written by Ibn Qayyim al-Jawziyyah and Pemakanan di dalam Al-Quran dan Al-Hadis written by Siti Rudainah Saleh. The study of pomegranate in magazines were too few in number with a brief discussion.

\section{CONTRIBUTION OF THE PREVIOUS RESEARCH}

Pomegranate contains $78 \%$ water, $1.6 \%$ protein, $0.1 \%$ fat, $5.1 \%$ fiber, carbohydrates $14.5 \%, 0.7 \%$ minerals and $14 \mathrm{mg} / 100 \mathrm{~g}$ ascorbic acid (vitamin C). The fruit is also rich in sodium, riboflavin, thiamin, niacin, vitamin $\mathrm{C}$, calcium and phosphorus. All parts of this plant contain tannins, especially on the skin of $26 \%, 10-25 \%$ stem bark and root bark of $28 \%$. Tannins are used to color the material from skin. Pomegranate bark and roots also contain alkaloids.

Pomegranate flowers can also be used mainly in the treatment of disease. In addition, the bright red flowers are also a source of natural dyes. A study conducted at the Universiy of California at Los Angeles have analyzed 10 types of drinks that have high power to fight disease. Results of the study found that pomegranate juice is best followed by red wine, grape juice, blueberry juice, black cherry juice, cranberry juice, orange juice, tea and apple juice.

In addition, the pomegranate is very significant for the health of the body with high antioxidant content with its main bioactive polyphenols elements. It has a capability of lowering blood pressure in patients with hypertension. Punicalagin is the main polyphenol antioxidants in pomegranate juice. A compound found only in pomegranates called punicalagin is shown to benefit the heart and blood vessels. It not only lowers cholesterol, but also lowers blood pressure and increases the speed at which heart blockages (atherosclerosis) melt away. Antioxidant activity was tested in vitro with pomegranate juice, punicalagin, pomegranate ellagic acid and tannins (polyphenols extracted from pomegranate juice). The experimental results revealed that whole pomegranate juice has more antioxidant activity of the substances.

Furthermore, pomegranate juice or extract found helpful for atherosclerosis. Intake of pomegranate juice a day is good for coronary heart patients. In one study, researchers have provided pomegranate juice for 45 patients suffering from coronary heart disease and myocardial ischemia every day for 3 months. Based on the data, the researchers concluded that pomegranate juice are able to reduce stress stimuli.

The clinical fantastic result about pomegranate juice has also been shown to reduce total cholesterol, low-density lipoprotein (LDL), the ratio of LDL / high density lipoprotein (HDL) and the ratio of total cholesterol HDL. These findings suggest that consumption of pomegranate juice can alter heart disease risk factors in patients with hyperlipidemia (lack of blood lipids).

Pomegranate also has anti-bacterial and anti-microbial. The results showed that the extract of pomegranate are able to fight against methicillin-sensitive-resistant (MRSA), Staphylococcus aureus Salmoneela typhi and Escherichia coli O157: H7. Studies in vitro showed anti-HIV-1 microbicide could potentially result from pomegranate. In the field of dentistry, hydroalcoholic extract (HAE) of pomegranate is very effective against dental plaque microorganisms.

In vivo studies performed on pomegranate oil, seed oil, fermented juice polyphenols and pericarp polyphenols on 
growth of human prostate cancer cells found to inhibit the growth of breast cancer cells dramatically, aggression and increased apoptosis (programmed cell death) in breast cancer cells . Pomegranate extract effectively repair the damage with UVA-mediated cell lines soften and prevent potential skin cancer. It can act as a barrier against enzymes that can damage the cartilage. Pomegranate juice is a remedy for skin damaged by sun and aging. It repairing damage to the skin smooth and youthful again. For people with Alzheimer's, pomegranate juice may help prevent and slow development.

From Islamic point of view, Ibn Sina (1037M), Ibn Qayyim (1292M) and al-Dhahabi $(1348 \mathrm{M})$ believes eating pomegranates can strengthen the heart, eliminate tapeworms, cure dysentery, nervous weakness, sore-throat inflammation. Pomegranate skin if boiled and when the water is drunk will stop diarrhea disease. Eat fresh pomegranate can reduce cholesterol levels and help digestion.

In addition, drinking pomegranate juice with honey will launch bowel function, eliminate constipation, eases breathing, blood cleansing and treating the wound injury. Muhammad al-Sayyid al-Arna'ut also said that pomegranate juice can soothe pain, fever and thirst. Dried pomegranate skin is good for cough, chest pain, lungs, heart, stomach, liver, digestion and treat diarrhea and infections of tapeworms.

After analyzing the findings of medical studies about pomegranate, it proved to be the fruit of paradise. This is because it has many benefits available with antioxidant benefits, anti-bacterial, anti-cancer, and also good for the heart, liver, sperm production, stomach, skin, brain, teeth, cartilage and wound injury.

\section{ADVANCED RESEARCH ON POMEGRANATE}

Health field that applies the herb is a broad field of study. There are many aspects that can be carried out a detailed study on the future whether in religion or science aspect. Here are a few suggestions fields and aspects related to these research;

a. Specific studies about pomegranate from a religious perspective is very little. Most studies of a general nature can be devoted to other aspects of the law and emphasize the usefulness of henna available from authentic traditions. This is due to the existence of hadith dhaif (a hadith which fails to reach the status of Hasan) quoted as evidence the efficacy of herbs and fruits in Islam.

b. The combination of discussion and analysis about pomegranate from the viewpoint of religion and science should be done. Until now, the search results data showed that only two publications that discuss the pomegranate with a combination of a religious viewpoint and perspective of science. It is at once can prove the truth of the teachings of Islam with proofs results of scientific analysis.

c. The existence of pomegranate products available in the market or used as a capable new products can be examined from the perspective of halal (lawful) and haram (unlawful). The results of the study can be used as a high-value products that can be sell in the market. Thus, the content of pomegranate should be studied from the aspect of its effectiveness to meet the needs of the community.

d. Henna species vary according to country. The study of pomegranate in Malaysia also not yet widespread. Research on pomegranate species found in Malaysia can be applied to produce health products Malaysia.

\section{CONCLUSION}

Pomegranate is a prophetic food that is valuable. It is not just a fruit that can be eaten but every aspect in pomegranate trees 
can provide health benefits and disease prevention. All aspects related studies to pomegranate should be examined in depth by academics to produce a product that is useful to all classes of society. Thus, the efforts of researchers from Universiti Malaya through grants TRGS (TR001A2014) entitled 'Safe and Health Uses of Fruits and Herbs Mentioned in Al-Quran and Ahadith: An Analysis of ethnomedicinal Importance in Islamic Products in Malaysia' very significant in the development of science. Advanced new study of pomegranate is expected to produce a new findings for the benefit of Malaysia.

\section{REFERENCES}

A. Esmaillzadeh et.al. 2006, 'CholesterolLowering Effect of Concentrated Pomegranate Juice Comsumption In Type II Diabetic Patients With Hyperlipidemia', International Journal Vitamin Nutritional Resources, 76(3)

A. Robert Neurath et.al. 2005. 'Punica Granatum (Pomegranate) Juice Provides An HIV-1 entry Inhibitor and Candidate Topical Microbicide', Annals of the New York Academy of Sciences, 1056(1)

Abu 'Abd Allah Muhammad bin Ahmad alDhahabi, 1990, Al-Tibb al-Nabawi, Beirut: Dar Ihya' al-'Ulum

Abu 'Ali al-Husayn bin 'Abd Allah Ibn Sina, 1998, Al-Qanun fi al-Tibb, Beirut: Muassasah al-Ma'arif, j. 2

Aviram et.al. 2004, "Pomegranate Juice Consumption for 3 Years by Patients With Carotied Artery Stenosis Reduces Common Carotid Intimamedia Thickness, Blood Pressure and LDL Oxidation", Clinical Nutrition, 23(3)

D. N. Syed et.al. 2006. 'Phtotchemopreventive Effect of Pomegranate Fruit Extract on UVA-Mediated Activation of Cellular Pathways In Normal Human Epidermal Keratinocytes', Photochem Photobiology, 82(2)

Fakhr al-Din al-Razi, Tafsir Fakhr al-Razi,
1994, Beirut: Dar al-Fikr, juz. VII, h. 115.

Ibn Qayyim al-Jawziyyah, Perubatan Rasullullah, (terj.) Nabilah Abd. Jalil, 2013, Selangor: Al-Hidayah House of Publishers Sdn. Bhd

Jamaluddin Mahran, 'Abd al-'Azim Hafna Mubashir, al-Ghadza' wa al-Dawa' fi al-Qur'an al-Karim, (terj.) AlQur'an Bertutur Tentang Makanan $\mathcal{E}$ Obat-Obatan, Yogyakarta: Mitra Pustaka

Julia F. Morton, 1987, Pomegranate dalam Fruits of Warm Climates, Miami, Florida: t.p.

L. C. Braga, et.al. 2005, 'Synergic Interaction Between Pomegranate Extract and Antibiotics Against Staphylococcus Aureus', Canadian Journal of Microbiology, 51(7)

Michael D. Summer et.al. 2005. 'Effects of Pomegranate Juice Consumption On Myocardial Perfusion In Patients with Coronary Heart Disease.' The American Journal of Cardiology, 96(6)

Muhammad al-Sayyid Arna'ut, 1998, Al$A^{\prime}$ 'shab wa al-Nabatat Ghiza' wa Dawa', Kaherah: al-Dar al-Misriyyah alLubnaniyyah

Munirah Abd Razzak, 2011, Punica Granatum Bicara Al-Qur'an Al-Hadith Dan Sains Perubatan Moden, Jurnal Al-Bayan, bil. 9 (1), Universiti Malaya: Jabatan Al-Qur'an dan AlHadith, Akademi Pengajian Islam

N. P. Seeram, et.al. 2005, 'In Vitro Antiproliferation, Apoptotic and Antioxidant Activities of Punicalagin, Ellagic Acid and A Total Pomegranate Tannin Extract Are Enhanced in Combination With Other Polphenols As Found In Pomegranate Juice, Journal of Nutritional Biochemistry

S. M. Menezes, L. N. Cordeiro dan G. S. Viana, 2006, 'Punica Granatum (Pomegranate) Extract Is Active Against Dental Plaque', Journal of Herbal Pharmacotheraphy, 6(2)

Shams al-Din Muhammad bin Abu Bakr 
Ibn Qayyim al-Jawziyyah, 1990, AlTibb al-Nabawi, Beirut: Dar al-Fikr

Soraya binti Mohamad Arsad @ Abdul Hamid. 2009. Pemakaian delima dalam masyarakat Melayu dan India: Kajian perbandingan menurut perspektif Islam. Jabatan Akidah Dan Pemikiran Islam Akademi Pengajian Islam Universiti Malaya

Tanner, Cory, 2009, "Pomegranate". Horticulture Extension Department, Clemson University, 21 June 2014.

\section{AUTHORS OF THE ARTICLE}

$>$ Khadher Ahmad: Senior Lecturer in Department of Quran and Hadith, Academy Of Islamic Studies, University of Malaya (UM), 50603, Kuala Lumpur, Malaysia. Tel: +603-79676046. E-mail: khadher82@um.edu.my,

> Mohd Yakub @ Zulkifli Mohd Yusoff: Professor in Tafseer, Department of Quran and Hadith, Academy Of Islamic Studies, University of Malaya (UM), 50603, Kuala Lumpur, Malaysia

$>$ Nurulwahidah Fauzi: Senior Lecturer, Faculty of Quranic and Sunnah Studies, Islamic Science University Of Malaysia, Bandar Baru Nilai, 71800, Nilai, Negeri Sembilan. Tel: +60102364683, email:wahidah@usim.edu.my

> Monika @ Munirah Abd Razzak, Mohd Asmadi Yakob: Lecturer, Academy of Contemporary Islamic Studies, Universiti Teknologi MARA (UiTM), 40450 Shah Alam, Selangor

$>$ Khalijah Awang: Professor in Department of Chemistry, Faculty of Science, University of Malaya

> Rozana Othman: Senior Lecturer in Department of Pharmacy, Faculty of Medicine, University of Malaya

> Mohd Farhan Md Ariffin: Postgraduate Student, Department of Quran and Hadith, Academy Of Islamic Studies, University of Malaya (UM), 50603, Kuala Lumpur, Malaysia. Tel: +6019-
2169194.

E-mail:

al.muqarrobiin@gmail.com 


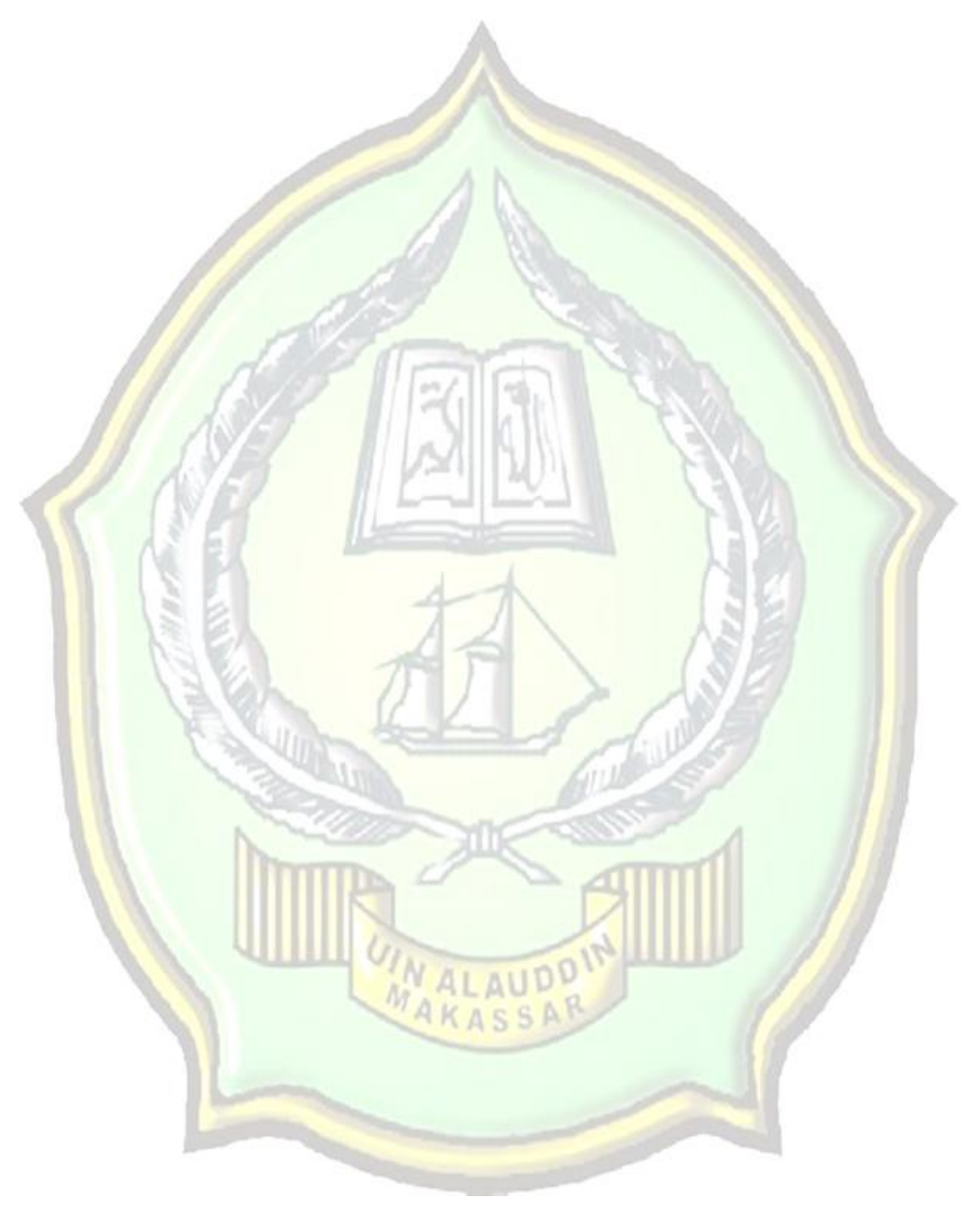

